\title{
Historicisizing World System Theory: Sugar and Coffee in Caribbean and in Chiapas
}

\author{
Dünya Sistemi Teorisini Tarihselleştirmek: Karayipler'de Şeker ve \\ Chiapas'ta Kahve Üretimi
}

\author{
Özgür BALKILIÇ**
}

\begin{abstract}
The world system theory has been developed during the 1960s and 1970s in order to explain the economic, political and cultural relationship between developed, developing and underdeveloped countries. The main assumption of this theory is that economic and political dynamics which have progressed from the late 16th century towards contemporary ages resulted in unequal and dependent relations between these countries. Consequently, while an advanced economy and consolidated democratic-political institutions emerged in the developed countries, the developing and underdeveloped countries whose natural resources and economic assets are being exploited by the core countries are subjected to a backward economy and politically unstable systems. However, the world system theory has not gone unchallenged; on the contrary, a considerable amount of social scientists accused it of being overwhelmingly functionalist. The main weaknesses of this theory are that it ignores the local Dynamics and it, related with the first point, reduces the lower classes to the passive recipients of historical transformations. In order to fulfill these gaps in the theory, several scholars, in an attempt to explain the expansion of capitalism in non-Western regions, focus on the local dynamics of commodity chains and labor processes in these localities. Following this criticism, this paper argues that the historical development of sugar and coffee production, both of which are the most important commodities of the world trade from the early 16th century cannot be explained ignoring the local dynamics and that the local aspect of labor strategies which are designed to keep the potential producers in the land and production process must be analyzed as an important factor in the historical development of the production of these two commodities. In doing so, the article will analyze the development of labor processes and strategies in sugar and coffee production in Caribbean in the 16th and 17th centuries and Mexico-Chiapas in the 19th century, respectively.
\end{abstract}

Keywords: The World System Theory, Labor Process, Sugar Production in Caribbean, Coffee Production in Chiapas

$\ddot{O} z$

Dünya sistemi teorisi 1960 'lı ve 1970 'li y1llarda gelişmemiş, gelişmekte olan ve gelişmiş ülkeler arasındaki iktisadi, siyasi ve kültürel ilişkileri açıklamak için geliştirildi. Teorinin temel varsayımı dünya ölçeğinde 16. yüzyıldan günümüze değin meydana gelen iktisadi ve siyasi gelişmelerin bu coğrafyalar arasında eşitsiz ve bağımlı ilişkilere yol açtı̆̆ıydı. Sonuç olarak, gelişmiş ülkelerde gelişkin bir ekonomi ve köklü demokratik-siyasi kurumlar ortaya çıkarken, doğal kaynaklarına ve iktisadi varlıklarına gelişkin ülkeler tarafindan el konulan gelişmemiş ve gelişmekte olan ülkelerde geri bir ekonomi ve istikrarsız bir siyasi sistem meydana gelmektedir. Ancak, araştırmacılar dünya sistemi teorisinin ciddi eksikleri olduğunu belirtmekten de geri durmadılar. Bu teorinin en ciddi eksiklikleri yerel tarihsel süreçleri dikkate almaması ve bu noktayla ilintili olarak da alt sınıfları tarihsel dönüşümlerin basit nesneleri durumuna indirgemesiydi. Bu eksikliği gidermek için araştırmacılar kapitalizmin Avrupa dışındaki coğrafyalarda yayılışını açıklarken meta zincirlerinin yerel dinamiklerine ve yerelliklerdeki emek süreçlerine eğildiler. Bu makalede, 16. yüzyıldan itibaren dünya ticaretinin en önemli metalarından ikisi olan şeker ve kahve üretiminin yerel dinamikleri hesaba katmadan anlaşılamayacağ vurgulanıyor ve özellikle potansiyel üreticiyi toprağa ve üretime bağlamak için uygulanan emek stratejilerinin yerel boyutlarının kahve ve șeker üretimini belirleyen faktörlerden biri olduğu iddia ediliyor. Bu anlamda, makale 16. ve 17. yüzyılda Karayipler'de şeker ve 19. yüzyılda Meksika-Chiapas'da kahve üretiminde emek süreçleri ve stratejileri üzerine odaklanıyor.

Anahtar Kelimeler: Dünya Sistemi Teorisi, Emek Süreci, Karayipler'de Şeker Üretimi, Chiapas'da Kahve Üretimi

\section{Introduction: World System Theory and Commodity Chain Approach}

World-System theory existed at the end of the 1960s and 1970s under highly anticolonial, anti-imperialist and nationalist political climate especially in the Third World

\footnotetext{
* Dr. Öğrt. Üyesi, Abdullah Gül Üniversitesi, İnsan ve Toplum Bilimleri Fakültesi, Sosyoloji Bölümü, balk9720@mylaurier.ca
}

Balıkçı, Ö., (2018). Dünya Sistemi Teorisini Tarihselleştirmek: Karayipler'de Şeker ve Chiapas'ta Kahve Üretimi, Gaziantep University Journal of Social Sciences, 17 (4), 1298-1310, Submission Date: 18-01-2018, Acceptance Date: 27-09-2018.

Araştırma Makalesi. 
Countries. The main aim of world-system theory as developed by Immanuel Wallerstein was to explain the unfair relations between core and periphery ${ }^{\dagger}$. In this relationship, according to world-system theory the social, economic and politic historical relations in the periphery were determined by the necessities of capitalism in the core. Although this theoretical school was highly attractive for the scholars who tried to explain increasing integration of the world especially after the fifteenth century, world-system theory was highly criticised for their functional assumptions and overgeneralizing ideas. It was stated that the main deficiency of it was to ignore the importance of local conditions of the periphery in its relationship with the core. In a similar vein, in this paper, I will criticize world-system theory by arguing that the labor strategies which were implemented in the Caribbean sugar plantations in the seventeenth and eighteenth centuries and coffee plantations in Chiapas in the nineteenth century developed by the local conditions rather than necessities of world system. Furthermore, I will argue that the workers in the plantations were active agents rather than the passive victims of the production processes.

World system theory's assumptions were highly influenced by dependency theory which was mainly developed by left-wing Latin American scholars to explain the reason of underdevelopment of their continent. Andre Gunder Frank can be counted as one of the dominant scholars in the dependency theory. Frank (1966, p. 18) in his highly influential development of underdevelopment thesis, argued underdevelopment in a particular country was the result of the "past and continuing economic and other relations between the satellite underdeveloped and the now developed metropolitan countries." That is, according to Frank, the capitalist system existed in the past centuries in the Western Europe, core countries, infiltrated the economic sectors in the periphery countries especially through the trade of certain commodities. In this sense, the function of the periphery in its relation with the core countries was to produce economic items and the function of the core was to transfer them to the world metropolis (Frank, 1966, p. 20). In this kind of relationship, fate of the periphery which was decided by the world-scale capitalist relations, was to remain as underdeveloped one (Frank, 1966, p. 23). Then the social, economic and other relations in the periphery regions began to be shaped by the interests of the core countries (Frank, 1966, p. 19).

Like Frank, the main concern of Immanuel Wallerstein, is the most influential figure of the world-system theory, was the explanation of how the capitalist system penetrated into the periphery and shaped the economic and social relations. For him (1974, p. 387), the main difference between Marxism and bourgeois ideologies was the former's method of analysis of its case by looking at the social whole, that is, from the perspectives of totality in a Lukacsian sense. This means that, for Wallerstein, capitalist production should be analysed by looking at a total world system from its beginning. The capitalist economic relations were dominant in all over the world for the centuries and it transformed all the other economic systems. In this sense, after emerging in the Western Europe, capitalism penetrated into the other parts of world by trade and transformed the world into its market (Wallerstein, 1974, p. 398). Wallerstein (1974, p. 415) claims no economic system, even the socialist economies could avoid from the world-system. And this system was the capitalist in its form; that is, the main sake of the system was to make profit. Like Frank, Wallerstein (1974, pp. 400-401) divides the world as core, periphery and semi-periphery countries and he defines a kind of division of labour between these countries. In this division of labor, the core countries appropriate the economic surplus produced by the periphery and semi-periphery countries. More importantly, the internal conditions of the periphery and semi-periphery countries, like state formation or

\footnotetext{
${ }^{\dagger}$ In the terminology of world-system theory, periphery refers to the Western European and North American countries which have a highly developed capitalist system and dominate and exploit the rest of the world, periphery, for the necessities of capitalism.
} 
class configuration, are determined by the interests of the world-system as well as their international positions. In this regard, it can be derived from Wallerstein assumptions that the core imposed capitalist social and economic relations to the periphery. In this narration, the local conditions as causal factors to explain the historical developments of the periphery were almost invisible.

Both dependency theory and world-system theory have been accused of reducing the capitalist production to the exchange of commodities and in this sense, not comprehending properly the qualitative breakthrough of capitalism from the earlier mode of production (Wood, 2002, p. 12). On the other hand, especially world-system theory perpetuated its effects on the scholars who try to understand the capitalist transformation in a global scale. Since the world-system theory focuses on the interaction of the different regions in a world scale, it continues to influence the scholars who are working on how the world integrated mostly due to trade relations between the countries especially after the sixteenth century in an accelerating speed. At that point, the commodity chain approach can be useful in order to explain the social, economic and cultural transformations in a global scale especially when looking at the "plantation colonies that were clearly export driven" (Schwartz, 2004, p. 6). In this sense, commodity chain approach emphasizes on the importance of commodities as a factor linking the different parts of the world together. For the scholars who work on the global scale, the different parts of the world were influenced by the commodity chains and production, distribution and consumption were determined by the movement of commodities. In other words, they followed the tracks of a particular commodity in order to explain the relations between the production, distribution and consumption processes.

Although the commodity chain approach highly inspired by Wallerstein's world system theory, it argues different sides of the commodity chain do not just develop in accordance with the sake of capitalism in the core countries. Rather, for the scholars who use this approach in their historical analysis the relations between the production, distribution and consumption develops in a dynamic way (Topik et al., 2006, p. 3). That means commodity chain approach gives importance to the local conditions to analyze repercussions of movement of a particular commodity in a global scale. In this sense, for example, the production process in a periphery country develops in accordance with the already existing the political, social and economic local characteristics of this country as well as the benefits of the core countries. Any scholars who deal with the integration of the different regions to the world capitalist system by looking at commodities should take historical differences of the regions and analyze integration mutually rather than just looking at the interests of the core countries. That means, rather than imposing their interests the core countries has to make some compromises in order to perpetuate their existence in the periphery. For these scholars, therefore local historical factors play crucial roles in development of the production of a particular commodity in the periphery. Furthermore, as historians Carlos Marichal et. al (2006, p. 353) claim that the commodity chain approach is not just a concept to comprehend the main dynamics economic transmission lines: "it also obliges the historian to focus on social history and consumption of export products." The social history of products also obliges the scholars to see the participants of the production in the periphery as the active agent of the commodity production rather than the passive victims. The sugar as a world commodity in the seventeenth and eighteenth century and coffee as another one in the nineteenth century are beneficial examples to show the importance of local conditions on the labor strategies in their production.

The sugar production in the plantations was carried to the Caribbean islands by the European colonists and sugar became the main world commodity between sixteenth and eighteenth centuries. Although increase in the sugar production in those centuries was caused 
by increasing demands from the Western Europe and the major European powers, Portugal, Spain, France, Dutch and Britain involved in the production of sugar, it is impossible to say that the Western European powers unilaterally determined every phase of production. They had to take into account the local conditions where the plantations were founded and one of their main concerns was to find and control available labor supplies. Likewise, one of the main problems of the coffee producers in Chiapas, Mexico was labor shortage. Although Chiapas was not colonized by the Western European powers unlike the Caribbean islands, the coffee production erupted in this region due to increasing demands in global scale. Therefore, the coffee produced in Chiapas was a world commodity from its beginning. On the other hand, like in sugar, the producers had to face the local obstacles to maintain their production.

\section{Sugar in the Caribbean Islands}

According to a prominent historian of the sugar trade, Sidney W. Mintz (1985, p. 21) sugar production can be brought back to the ancient times. Before European production in the South America, sugar cane was cultivated in different parts of the world. Arab expansion to the westward in the seventh and eight centuries disseminated the sugar production into the Mediterranean region. From the thirteenth to the fifteenth century, the Cyprus was the main production center for sugar consumed in Europe. The Europeans immensely contacted with the sugar production in the Crusades. By adopting the Muslim techniques, the crusaders cultivated the sugar cane in Northern Lebanon. In those decades, sugar was also produced in the Southern Italy but on a limited scale (Curtin, 1999, pp. 5-7). After some time, Spain became another region in which sugar was produced. On the other hand, the scale of the sugar lands in Italy and Spain and the relative weight of sugar trade in the Mediterranean economy were very small. After the Mediterranean, sugar cane was carried to the Madeira and Canary islands and after some armed conflicts, these islands were begun to be controlled by the Spanish in the fifteenth century. Then, Spanish sugar production moved to the Atlantic islands in 1490s. Sugar cane was carried to the Latin America by Columbus in 1493 in his second voyage and it was first cultivated in Santa Domingo.

The sugar production in Italy and Spain encountered some obstacles, since the cultivation of sugar cane requires tropical and subtropical climates and sugar production also needs large amounts of water and labor (Mintz, 1985, pp. 21-25). Especially in Iberia, abundant water and warm growing conditions were not available (Phillips, 2004, p. 27). So, the sugar plantations played in the Mediterranean a kind of stationary role which carried the sugar to the Atlantic islands (Phillips, 2004, 38). Like in Italy and Spain, Both of Madeira and Canary islands had very few suitable lands for the sugar production (Curtin, 1999, 21). Therefore, the European sugar production was not very successful before the sugar cane was carried to the Atlantic.

It is hard to say that first Spanish attempts to produce sugar were successful in the Caribbean. The Caribbean islands had geographic advantages on the sugar production. For example, most of the best sugar land was near the coast, "so that barrels o sugar could be rolled to the beach and transhipped by lighter to seagoing vessels" (Curtin, 1999, pp. 75-76). Moreover, the suitable winds in the season made transportation easy for the ships. Furthermore, the average rainfalls in a year, especially in Barbados, were favourable for the sugar cane production. Despite all these geographic advantages, Spanish sugar production in the Caribbean was not successful mostly due to the labor shortage. The Spanish could not solve this problem in this region and therefore the Caribbean islands could not compete with the sugar production in Brazil which was in the hands of the Portuguese. In result, the sugar production was a stabilized one in Caribbean. After some time, the Dutch began to dominate the islands. But, they just traded the finished goods and did not involve in the production of sugar. Meanwhile, Britain began to establish colonies in Caribbean in the second decade of 
1600s, especially in the Barbados Island (Curtin, 1999, pp. 77-78). Unlike the Spanish, the British were very successful in the sugar production in Caribbean. They incredibly increased the amount of sugar production to meet their internal sugar demands. As a result, with the growing influence of Caribbean sugar production in the world sugar market, Britain became the dominant actor of the sugar production.

Before English, the Dutch was dominant power in the international sugar market. On the other hand, the Dutch themselves did not participate in the cultivation of the sugar cane. Instead, they provided money, credit and labor supply to the producers (Wolf, 2010, p. 197). In this sense, the turning point of sugar industry was the entry of Britain to the international sugar market and cultivation of sugar cane in the Barbados Island in the second half of the seventeenth century. Mintz (1985, p. 38) argues:

England fought the most, conquered the most colonies, imported the most slaves (to her own colonies and, in absolute numbers, in her own bottoms), and went furthest and fastest in creating a plantation system. The most important product of that system was sugar. (...) the amount of sugar produced, the numbers of its users, and the range of its uses exceeded the others [Portuguese, Spanish and Dutch]; and it remained the principal product for centuries. In 1625, Portuqal was supplying nearly all of Europe with sugar from Brazil. But the English soon developed their sources in Barbados and then in Jamaica, as well as in other 'sugar islands'.

England's entry to the sugar market was firstly for the counterbalance of the growing domestic demand for sugar. But, accelerating sugar production also provided England strength in the European market. Both domestic demand and rivalry in the international scale required unceasing sugar production (Mintz, 1985, p. 45). To counterbalance these, strict labor strategies were implemented by the plantation owners since from its beginning, the sugar industry in the New World suffered from the labor shortage and consequently slave labor began to be used in the plantations (Mintz, 1985, pp. 32-33).

Plantation was a place which combined the farming of the cane processing of its juice into sugar (Schwartz, 2004, p. 3). Both the cultivation and refinement of sugar was realized in the plantations. In this sense, one of the features of the sugar plantations was the unusual combinations of agricultural and industrial forms in Caribbean. Another feature was that sugar as a crop was monopolized. Sugar monoculture has eroded the diversified farming in Caribbean. For example, by 1645, sugar cane was cultivated in the 40 percent of the Barbados Island and by 1767 this ratio has risen to 80 (Curtin, 1999, p. 83). As a third feature, the plantations were in large scale and owned by the private individuals. In all Caribbean, sugar production was made in the large plantations (Wolf, 2010: p. 151). The small holders gradually became poor whites and they were replaced by the large owners.

One of the main concerns of the big plantation owners was the labor force issue. The cultivation and process of sugar necessitated the proper climate and hard labor. In addition, a solid technical mastery was necessary for processing sugar. Boiling and striking of sugar cane required great skill. The labor force worked as the labor gangs that maintained the repetitive and arduous tasks which required strict sequence and synchronization (Wolf, 2010, p. 315). In this sense, Mintz (1985, p. 51) claims labor discipline was the first issue to be implemented in order to arrange properly the complex production process of sugar. Second issue was the organization of skilled and unskilled labor force in accordance with the production goals of plantation. The labor force was composed of interchangeable units. And last issue is that the system was time-consciousness which penetrated all phases of plantation life. That means, the daily life in the plantations was strictly scheduled and controlled to provide time discipline. Wolf (2010, p. 315). emphasizes on the necessity of strict managerial control by claiming that a plantation can be defined "as a capital using unit employing a large labor force under close managerial supervision to produce crop for sale." The labor issue was so important in 
Caribbean that, the issue of labor force has changed the social, political and economic landscape of island: "(...) the nature of labor supply, the character of the population, and the organization of the workforce, and that it mightily to the reconfiguring of the social, economic, and political landscape" (Mccusker and Menard, 2004, p. 290). The large plantation owners provided all these work place requirements to a certain degree. In this sense, it should be said that their main problem regarding labor was to find the available labor forces which was a major problem of the sugar production from its beginning in Atlantic to recruit in the plantations.

The plantation owners used different kind of labor in order to challenge the labor shortage problem in Caribbean. They firstly used the contracted laborers, also called as indentured servants. They were settlers from the mother country, England, and they were the debt servants, petty criminals, political and religious non-conformists etc. English carried these people to the region where the sugar production was maintained. Since the cost of using indentured servants in the plantations was less, the owners preferred them. On the other hand, there were certain obstacles to use the contracted labourers in the plantations. Indenture was limited in time, "hedged about with customary and legal restrictions, and subject to the relative ease with which servants could escape" (Wolf, 2010, p. 202). When their contracts ended, they were given some tracts of land of their own. So "the new colonies would presumably fill up with settlers over time" (Mintz, 1985, p. 52). In fact, the population for example, in the Barbados Island increased due to the importation of indentured servants from England (Mccusker and Menard, 2004, p. 292). But Wolf (2010, p. 202) claims that only two out of ten between 1607 and 1776 could attain the status of independent farmers or artisans. Indeed, in practice the conditions of the indentured servants were not very different from those of the slaves. They were bought and sold "while contractually bound." They were severely punished if they did not obey the rules and broke the discipline. In short, using indentured servants could not supply the deficiency of labor in Caribbean.

In the 1630s the slave population was very rare in the Caribbean. And the number of slaves was insufficient to meet the increasing labor demand due to the increasing sugar production. Thus, the native enslaved people were put in the plantations to work along with the indentured servants. But the problem of using the native people was that although the Caribbean islands were densely populated, most of native population had been wiped out by the European disease. Furthermore, since some of them were converted into Christianity, they could not be enslaved (Curtin, 1999, p. 63). To conclude that point the plantation owners could not benefit from the native labor force as much as they hoped. In this case, the problem of labor shortage could not be solved either by the indentured servants or by the local indigenous population. After that, the slave people from Africa and India began to be imported to work in the plantations (Mintz, 1985, p. 53).

As one of the prominent scholars on the Atlantic slave trade, Herbert Klein (2004, p. 201) suggests that the slave trade had evolved independently from the expansion of sugar economy. Europe knew the slavery as an institution before the Atlantic slave trade and the slavery existed in Africa from the recorded times. The arrival of the Portuguese initiated the African slave trade in the early $1400 \mathrm{~s}$, but the slaves never became the dominant labor force in the local economies in Europe (Klein, 2004, pp. 202-203). With the expansion of sugar production in the Atlantic islands and labor scarcity mostly caused by the decimation of the native population by the European disease, the European merchants began to import African slaves in order to make them labor force in the sugar plantations (Klein, 2004, pp. 204-206). In the 1600 s the slave trade was directly tied with the sugar production in the Atlantic. The Portuguese was the first people to import to slave to work in the sugar plantations in Sao Tome near to the African cost: 
By the 1520s, Sao Tome's own sugar industry had begun to grow, and the island made a convenient center for the slave trade as well. Sao Tome imported about 2.000 slaves a year from all sources. The Portuguese on the island put some of them to work on local sugar plantations (Curtis, 1999, p. 43).

It should be added here that the emergence of sugar production did not bring slavery to the Caribbean the sugar just intensified the already existing process (Mccusker and Menard, 2004, p. 294). After the late seventeenth century the number of slaves working in the Caribbean plantations rose sharply. The English Royal African company transported the African slaves to the English colonies (Klein, 2004, p. 215). From 1701 to 1810 in Barbados the number of imported slaves from Africa was 252.500 and the same number in Jamaica between the same years was 662.400. By 1680, the number of slaves in the islands became adequate for the production (Mccusker and Menard, 2004, p. 301). These had been mostly dispossessed people in their own countries but not as free landless workers, as slaves. Like modern proletarians, they were estranged from the means of production and they were dispossessed. But, unlike the free wage laborer they had nothing to sell, even their labor force. Instead they were themselves bought and sold (Mintz, 1985, 54-57).

Wolf (2010, pp. 203-204) indicates that the African slave labor force was preferred rather than the indigenous workers since the Indian proximity to their native groups could encourage the rebelliousness. But the African slaves lacked such support. The colour of their skins was the marker of them and in case of their running they became easy targets for those who "bent upon reaping a reward." Consequently, "the enslavement of Africans thus offered the possibility of a labor force that could be set to work in arduous and continuous operations under an owner's direction, with restraints of law and custom reduced to a minimum." Despite all strict supervisions on them, the slaves in the Caribbean had two options to abandon their miserable condition in the plantations: running away or rebel. According to one prominent historian on the sugar plantations, Philip D. Curtin (1999, p. 104), the slaves could "defend a small territorial enclave against the Europeans' effort at conquest and reenslavement." These independent Africans could build some kind of colonies and began to be called as maroons in Caribbean. Indeed, these colonies had existed before the English occupation of the Caribbean islands. On the other hand, maroons continued to exist under the British colonial regime in Caribbean. For example, after the British forces invaded Jamaica in 1655, the Jamaican colonial government let them alone at first. But, in the early eighteenth century the government organized some military expeditions against the maroon colonies with varying success. Eventually, the government recognized their rights on the certain pieces of land.

The Caribbean islands witnessed the interaction of people from the different parts of the world. British population have managed the trade and production in the sugar plantations. In the plantations they used different kind of workers. They employed the indentured servants and slave labor force (Schwartz, 2004, p. 21). Neither implementing different kind of workers was presupposed by the sugar producers nor it was imposed by the world market for which sugar production was maintained. Rather, the historical and unpredictable conditions determined the usage of these types of labor. In this sense, local conditions, mainly labor shortage, were more effective than the interests of the world system to determine the labor strategy implemented in the Caribbean sugar plantations in the seventeenth and eighteenth century. Furthermore, the workers had some options to escape from unbearable process of the sugar production like running away or rebel. In fact, as in the case of Jamaica they used one of these options and eventually the colonial government had to make a compromise with them. That means, they were not the passive victims of the world history. Their life had not to be determined by the profit sakes of the sugar production. Even under the worst terrible conditions, they could hold their own fate in their hands. 


\section{Coffee in Chiapas}

As world historians Steven Topik and William Gervase Clarence-Smith (2003, p. 2) argue coffee is a worthy of attention since it has been an important one in the world economy and affected the lives of millions of people. That means, like sugar, coffee was another world commodity in history. Coffee production has erupted in the nineteenth century mainly in Brazil, Guatemala, and Mexico. Coffee production emerged in Chiapas, Mexico at the end of the nineteenth century in order to meet the increasing world demand. This region was not a colonized one. In this sense, free labor was used in the coffee plantations in Chiapas. These are the differences of the coffee production in Chiapas from the sugar production in Caribbean. But some similarities existed, too. The plantation owners in Chiapas encountered challenge of labor shortage similar to the plantation owners did in Caribbean and made some effort to capture the labor force like the sugar producers did in Caribbean. Moreover, laborer followed some strategies to escape from their miserable conditions and in this regard they were the active agents of the coffee production process in this region.

Coffee was mainly produced by the population of the tropic countries and consumed by those of temperate regions in the nineteenth century. Unlike sugar, most coffee producers were the independent Latin American countries since the middle of this century. Historically the coffee production had begun to be disseminated to the different parts of the world by the Muslim pilgrims but not European merchants. Yemen had been one of the original places coffee production and exportation before 1500. The production was in the hands of Yemen state. But, merchandizing coffee to Europe and the other parts of the world was made by the private individuals (Topik, 2003, p. 26). Apart from Yemen, the other important coffee producer was Ethiopia. The coffee was both produced in Yemen and Ethiopia was consumed in the Muslim world (Tuchscherer, 2003, p. 50). The Muslim pilgrims in the seventeenth century planted the coffee in India. Then, by taking the seedlings from India, Dutch planted the coffee in Java in 1690s. In the beginning of coffee as a world commodity, Dutch dominated the world market. But, as they did in the sugar plantations in Caribbean, they never involved in the production, they just traded the finished goods (Topik, 2003, p. 27). By the colonial expansion of Europeans in between the sixteenth and eighteenth century in the Caribbean and Latin America, coffee became one of the natural crops planted in the colonial lands. By the late eighteenth century the coffee production and trade in Latin America began to exceed that of Yemen. (Topik, 2003, 29). But it was still as a luxury good and heavily taxed by the governments.

In the meantime the coffee cultivation exploded in the mid-nineteenth century especially in Brazil due to technological improvements, construction of modern railroads, and shipping revolution. By the mid nineteenth century, Brazil was providing the half of world demand (Samper and Topik, 2006, pp. 124-126). This coffee boom led to huge tax reductions in the Europe. With these developments, coffee became an important part of daily diet of ordinary people especially in North America and Europe (Smith and Topik, 2003, p. 7). It means that the conditions became favourable for the mass production of coffee.

Although Brazil dominated the coffee production in the late nineteenth century, some other areas in Latin America, especially Chiapas, Mexico and Guatemala entered coffee production as well. The main problem of coffee plantation owners was labor shortage in Mexico. The coffee production in Mexico was encouraged by the high prices on the international market, "by the Mexican government's offer of vast extensions of fertile land for as little as two pesos a hectare," and by its promise of copious cheap labor force to the plantation owners in the mid-1890s. Then, more than four millions of coffee trees were planted in Mexico. The planters, by knowing that they had to wait five to seven years before the trees matured, planned to recruit the necessary labor force in the meantime. They planned 
to draw the labor force among the communities settled in the Chiapas's Central Highlands since prospectuses distributed in Mexico, the United States and Europe had promised the plantation owners "the marriage of the fertile tropical soils of the state's lowlands with the plentiful indigenous labor of its highlands." No one among the producers thought that the arrangements of labor transfer to the coffee plantations could not be completed until the mid1890s. As contrary to their expectations there would be few workers to harvest the crop even in the 1895. Although adequate labor force was recruited at the end of story, the important question remains as that in what ways did the producers transferred the local populations to the plantations (Rus, 2003, pp. 257-258).

Chiapas can be geographically divided into two parts as lowland and highland. Coffee was planned to be cultivated in the lowland region. The lowland investors thought that they would easily find labor force among the native population which had no land and was living under the isolated conditions. First of all, in Chiapas, the state legislations took the communal rights of indigenous communities on lands from their hands. By the mid nineteenth century the native communities in Chiapas lost most of their territorial base (Wolf, 2010, p. 337). And secondly, the native populations of highland were living in their tightly organized communities. They were speaking their own languages and wearing their own distinct clothes. The producers had thought that these isolated, primitive communities would jump to enormous possibilities provided by the money economy (Rus, 2003, p. 261). In fact, however, these native communities were not living under the complete isolated conditions. They were managed by the non-Indian elites as the labor reserves:

Indeed, much Indian labor continued to be requisitioned directly - if illegally- through mechanisms that were in effect a continuation of the colonial repartimiento under which communities had been collectively responsible for providing workers to private employers in order to be able to pay their church taxes and tribute to the Crown. As cases from throughout the state, but especially the highlands, attest, still in the 1880s ladino (non-Indian) landowners and merchants were notifying Indian town councils of their labor requirements, paying them a pittance in advance - called an habilitacion, or 'enabling payment' - and then receiving adult male workers as a levy (Rus, 2003, p. 261).

It can be derived from this picture that labor strategies to find the labor force in the production of coffee as a world commodity in Chiapas developed as the result of local conditions but not the necessities of the world coffee market. In this picture, the lowland agricultural investors in Chiapas had to struggle with the highland elites to extract the necessary labor force. In this struggle, Mexican state would help the lowland elites.

Indigenous people in highland Chiapas were tied to their elites by several ways. Indigenous people were bounded by the obligations of the labor force when it was necessary. These obligations were seen by Indian people as the price of their internal political and social autonomy. But since it was imposed to them by the outside world, they were also prone to resist to this obligation. In addition to this obligation, the highland landowners in Chiapas highly benefited from the 1826 legislation which permitted the non-Indian landowners to claim untitled communal lands. For example, after that legislation, the landowners had the right to transform entire village to their tenants. In this case, Indians had to work three or four days a month in the lands of the non-Indian landowners to perpetuate their life in their own houses and fields. The Indian labor force was also tied to land by debt. Although the liberal Mexican Constitution of 1857 outlawed the involuntary labor, wage advance given to the workers was redefined as loan (Rus, 2003: p. 262). In this way, another kind of obligation was implemented to Indian labor force. Despite all these mandatory works, the daily life of Indian communities was not totally disrupted. The indigenous people still could attend their own fields and activities (Rus, 2003, pp. 263-264). 
Nevertheless, by the 1870 s daily life of indigenous population was begun to be totally destroyed. In addition to highland elites, the lowland elites demanded to benefit from indigenous population. The ties of the native population to their elites in general were intensified especially by the government's measures. The government began to encourage the cultivation of agricultural crops in Chiapas in the 1870's. Meanwhile, the local elites were "moving aggressively to privatize remaining public lands and legalize their control of at least their own region's work forces" (Rus, 2003, pp. 264-265). In this sense, the lowland landowners had to capture the residents of the new lands in the highland regions to perpetuate the production. Then, they intensified their extralegal control by making contractual relationships with the workers. Moreover, the town councils in highland Chiapas were made responsible for the tax collections and with the 1880 statute the workers and their debts were registered with the departmental governments. If the workers tried to escape from the lands without clearing their accounts, they could be put into jail by the police forces (Rus, 2003, p. 265). All these developments intensified the control of both state and landowners on the labor reserves among the native population.

As convinced from the promise of Mexican government on the availability of fertile land and abundance of cheap labor, foreign investors and lowland elite began to cultivate the coffee beans in the lowland Chiapas in the 1890s. On the other hand, the main problem of the new coffee plantation owners was to find the available workers to be employed in the land. When they realized that the Chiapas highland indigenous people were immobile and tied to highland elites, the federal government helped the foreign and local lowland plantation owners to provide labor supply which was necessary for coffee production. For this aim, a government agent, Emilio Rabasa was sent to the region. He mainly tried to break the control of the highland elites on the indigenous community by making fiscal and customs reform, road and bridge building, moving the state capital from San Cristobal to Tuxtla Gutierrez in Chiapas's Central Valley, and replacing the existing government bureaucracy with his trusted colleagues. (Rus, 2003, pp. 272-273). Meanwhile, in order to induce Indian population to work in the lowland, Rabasa "decreed the sale of their village's communal holdings, or ejidos, updated the tax rolls to improve the collection of capitacion, and reinvigorated the 1880 vagrancy laws for those who failed to pay." He also bolstered the police force and administration to implement these regulations. He, furthermore, argued that indigenous people needed to be educated to be useful work force in the plantations (Rus, 2003, p. 274). Nevertheless, most of Rabasa's efforts failed in success:

\begin{abstract}
Rather than improving the labor flows to the lowlands, the new taxes and improved enforcement of vagrancy laws actually facilitated the highland elite's ongoing conversion of its hold on their labor from extralegal, customary conscription into legal contracting based on wage advances. Meanwhile, the sale of the ejidos - which around the state were typically bought by local elites - converted still more village Indians into tenants. As for the new mid- and low-level administrative and police positions, they were generally filled by clients of the local elites, meaning that state now paid minions of those elites to enforce their hegemony. Even the schools quickly became a means of further indebting rural people through unregulated 'taxes' for buildings, teachers, and materials (Rus, 2003, p. 275).
\end{abstract}

Rabasa's efforts to replace the existing bureaucracy with his man deepened the hostility of highland elites. Moreover, highland elites recognized that these reforms would undermine their traditional authority in the region and they resisted those efforts which would transfer their Indians to the lowland regions. Finally, Rabasa realized in 1893-1894 coffee picking season that that his reforms both created new discomforts among local elites and failed in success to transfer the workers to the lowlands. Thus, he changed his labor strategy. He temporarily accepted the system of obligated labor (Rus, 2003, pp. 275-276).

After Rabasa, the new governor of the region, Francisco Leon renewed government's efforts to undermine the power of the highland elites in Chiapas. For this aim, he deprived 
San Cristobal of the better part of its hinterland in 1896 by redrawing the departmental boundaries in the highlands. And he created a new administrative entity, the Partido de Chamula, which placed 90 percent of Tzotzil population under direct control of the federal and state governments and the lowland planters. But, these new administrative measures of Leon to extract the labor reserve from the highlands did not become successful. In 1896 coffee harvest, few indigenous people worked in the lowland plantations (Rus, 2003, p. 278).

On the other hand, Rus (2003, pp. 279-280) claims that, although it is not clear what mechanism drove the indigenous highland population to work in the lowland plantations, by 1897 and 1898 increasing amount of indebted workers eventually came to work in the lowlands. Nevertheless, the time period between 1897 and 1904 witnessed the fall of coffee production in Chiapas due to the annihilation of crops by volcanic eruption in 1902 and price falls in 1897 and consequently demand for workers decreased. After 1904, the demand for labor force increased again in Chiapas and in this time highland elites agreed to sell their labor reserve. More importantly, the lowland planters and government had laid their insistence on the free labor force and adopted a modified system of indebted labor which would be controlled by highland elites. Although the labor problem of the lowlands seemed eventually to be solved, use of indebted labor drove many plantation owners to the bankruptcy since "they were unable to service the debts they themselves had contracted to cover the wage advance loans originated by their hiring agents." Therefore, their struggle to get the control of labor reserves lasted for three more decades (Rus, 2003, p. 281).

This account of labor strategy in the late nineteenth and beginning of twentieth century in Chiapas shows that the indigenous community in Chiapas region resembles a gazelle between the lions and tigers. Despite all the lowland plantation owners' and government agents' discourse on the 'free labor', coffee production in Chiapas transformed indigenous people to be controlled communities by both lowland and highland elites. In this sense, as Rus (2003, p. 283) argues, they were recolonized but not emancipated. At this point, it can be asked that whether indigenous laborers were the passive victims of these complex historical developments or they somehow tried to be active agents as much as they could? Like slaves in Caribbean sugar plantations they acted in several ways to abandon their deteriorating conditions. First of all, they complained about their conditions to anyone who would listen. And secondly, they actively participated in the opening riots of Mexico's decade of Revolution in 1910-11 by overthrowing their traditional highland supervisors and government officers (Rus, 2003, p. 284). These mean, when they had the chance, they did everything in order to transgress the boundaries drawn by either the lowland and highland elites of Chiapas or the governments as the slave labourers did in the Caribbean sugar plantations.

\section{Conclusion: Looking Historically to World-System Theory}

As one of Latin American scholars, Jeremy Adelman (2004, p. 400) suggests that the historical scholarly works on Latin American history hugely contributed to make the world history. In this sense, the local histories of Latin America strengthened the argument that "the structuring processes of world history create deep unevenness, inequalities, and new cycles of fragmentation." On the one hand, these local historical accounts bolster world system theory by linking the social, economic, political and cultural developments of the localities to the world processes especially after the fifteenth century. On the other hand, they challenged one of the main assumptions of world system theory which emphasizes that the historical processes in all over the world were determined in accordance with the interests of the capitalist world system.

In this sense, it can be derived that world system theory as developed by Immanuel Wallerstein is inadequate to explain historical dynamics of integration of the world. As 
historian Steve J. Stern (1988, pp. 854-863) in his provocative essay about feudalism, capitalism and world system theory claims that the main paradigms of this theory, for example, on the development of the labor system in the periphery are misleading on both descriptive and explanatory grounds in the labor strategies of the silver mines and sugar plantations. For him:

In both cases, the emerging world-system remains important as a concept explaining America's subjugation to mercantile exploitation. But its power to reduce the periphery to functionally optimal role serving the core of international capitalism proves more contingent - more constrained, buffered, and driven by the force of independent causal 'motors' and by internal contradictions - than is suggested by Wallerstein's theoretical framework (Stern, 1988, pp. 863-864).

On the other hand, Stern (1988, p. 871) is right when he argues that world system approach has not to be abandoned. Rather, it should be enriched by the popular resistance and survival strategies within the periphery and mercantile and elite interests. In addition to Stern's points, world system theory should be also enriched by giving local conditions first priority in explaining the articulation of localities to the world system. In this sense, this theory should be tested and revised by looking at the historical cases.

Analyzing the labor relations and labor strategies in case of Caribbean islands in the seventeenth and eighteenth century and Chiapas region in the nineteenth century shows that the labor relations and strategies in the periphery, first of all, were not predetermined by the interests of the core countries; rather, they were historically determined. In this sense, secondly, internal social, political, and economic conditions of a particular periphery played crucial factors as well as impositions of the core countries in developments of the labor strategies in Caribbean sugar and Chiapas lowland coffee productions. And lastly, rather than the passive victims of labor processes in the plantations, the laborers were the active agents of the production processes which immensely affected their life. The laborers followed different strategies to transgress the limits imposed by whether the plantation owners or capitalist agents of world system. In this sense, the laborers sometimes rebelled openly to the plantation owners and state officials. Sometimes they developed some other indirect strategies to escape from their conditions. Therefore, the laborers have to be counted as a crucial factor when analyzing the integration of any particular region to the world system in general.

\section{References}

Adelman, J. (2004). Latin America and world histories: Old and new approaches to the pluribus and unum. Hispanic American Historical Review, 84(3), 399-409.

Clarence-Smith, W. G. and Topik, S. (2003). Introduction: Coffee and Global Development. W. G. Clarence-Smith and S. Topik (Ed.), The global coffee economy in Africa, Asia, and Latin America, 1500-1989 (pp. 1-21). Cambridge: Cambridge University Press.

Curtin, P. D. (1999). The rise and fall of the plantation complex. Cambridge: Cambridge University Press.

Frank, A. G. (1966). The development of underdevelopment. Monthly Review, 18(4), 17-31.

Klein, H. (2004). The Atlantic slave trade to 1650. B. Schwartz (Ed.), Tropical babylons: Sugar and the making of the Atlantic World (pp. 201-236). Chapel Hill \& London: The University of North Carolina Press.

Marichal, C. et al. (2006). Conclusion. S. Topik, C. Marichal and Z. Frank (Ed.), From silver to cocaine: Latin American commodity chains and the building of the world economy, 1500-2000 (pp. 352-360). Durham and London: Duke University Press.

Mccusker, J. J. and Menard, R. R. (2004). The sugar industry in the seventeenth century: A new perspective on the barbadian 'sugar revolution'." B. Schwartz (Ed.), Tropical babylons: Sugar and the making of the Atlantic World (pp. 289-330). Chapel Hill \& London: The University of North Carolina Press. 
Mintz, S. W. (1985). Sweetness and power: The place of sugar in modern history. New York: Penguin Books.

Phillips, W. D. (2004). Sugar in Iberia. B. Schwartz (Ed.), Tropical babylons: Sugar and the making of the Atlantic World (pp. 27-41). Chapel Hill \& London: The University of North Carolina Press.

Rus, J. (2003). Coffee and the recolonization of highland Chiapas, Mexico: Indian communities and plantation labor, 1892-1912. W. G. Clarence-Smith and S. Topik (Ed.), The global coffee economy in Africa, Asia, and Latin America, 1500-1989 (pp. 257-285). Cambridge: Cambridge University Press.

Samper, M. and Topik, S. (2006). The Latin American coffee commodity chain: Brazil and Costa Rica. S. Topik, C. Marichal and Z. Frank (Ed.), From silver to cocaine: Latin American commodity chains and the building of the world economy, 1500-2000 (pp. 118-146). Durham and London: Duke University Press.

Schwartz, S. B. (2004). Introduction. B. Schwartz (Ed.), Tropical babylons: Sugar and the making of the Atlantic World (pp. 1-26). Chapel Hill \& London: The University of North Carolina Press.

Stern, S. J. (1988). Feudalism, capitalism, and the world-system in the perspective of Latin America and the Caribbean. The American Historical Review, 93(4), 829-872.

Topik, S. (2003). The integration of the world coffee market. W. G. Clarence-Smith and S. Topik (Ed.), The global coffee economy in Africa, Asia, and Latin America, 1500-1989 (pp. 21-49). Cambridge: Cambridge University Press.

Topik, S.,Marichal, C. and Frank Z. (2006). Introduction. S. Topik, C. Marichal and Z. Frank (Ed.), From silver to cocaine: Latin American commodity chains and the building of the world economy, 1500-2000 (pp. 1-24). Durham and London: Duke University Press.

Tuchscherer, M. (2003). Coffee in the Red Sea from the sixteenth to the nineteenth century. W. G. Clarence-Smith and S. Topik (Ed.), The global coffee economy in Africa, Asia, and Latin America, 1500-1989 (pp. 50-66). Cambridge: Cambridge University Press.

Wallerstein, I. (1974). The rise and future demise of the World capitalist system: Concepts for comparative analysis. Comparative Studies in Society and History, 16(4), 387-415.

Wolf, E R. (2010). Europe and the people without history. Berkeley: University of California Press.

Wood, E. M. (2002). The origin of capitalism: A Longer View. London \& New York: Verso. 